\title{
MICROPROPAGATION OF MUNTINGIA CALABURA L. AND ASSESSMENT OF GENETIC FIDELITY OF IN VITRO RAISED PLANTS USING ISSR AND RAPD ANALYSIS
}

\author{
Suvarchala VANKUDOTH ${ }^{1}$, Ramakrishna DASARI ${ }^{2}$, Pavani CHIRUMAMILLA ${ }^{1,3}$, \\ Chaitanya GOPU ${ }^{1}$, Phanikanth JOGAM ${ }^{1}$, Srinivas KOTA ${ }^{1}$, $\underline{\text { Shasthree TADURI }}^{{ }^{*}}$ \\ ${ }^{1}$ Department of Biotechnology, Kakatiya University, Warangal - India \\ ${ }^{2}$ Department of Biotechnology, Telangana University, Nizamabad - India \\ ${ }^{3}$ Department of Biotechnology, Singareni Collieries Women's College, Kothagudem - India \\ *Corresponding author. E-mails: shastritaduri@gmail.com, tadurishasthree@kakatiya.ac.in
}

\begin{abstract}
Muntingia calabura L. is a potent medicinal plant. Because of that several researchers reported phytochemical and pharmacological studies, but only minimal information is obtainable on tissue culture and genetic stability evaluation studies. Therefore, in the present investigation we attempted to establish a reliable direct and indirect regeneration study through leaf and node explants on MS medium containing cytokinins BAP and $\mathrm{KN}\left(0.5-3.0 \mathrm{mg} \mathrm{l}^{-1}\right)$ in combination with auxins IAA and NAA $\left(0.5 \mathrm{mg} \mathrm{l}^{-1}\right)$. The breakage of bud and shoot initiation were noticed with the initiation of callus at lower concentrations of auxin alone at $0.5 \mathrm{mg} \mathrm{l}^{-1}$. 2,4-D was found to be good in callus induction from leaf and nodal explants. A problem of browning callus was prevented by regular subculturing of callus cultures. Leaf explants exhibited maximum number of shoots (32 $\pm 0.88 a)$ with shoot length (7.6 $\pm 0.17 \mathrm{a})$ and nodal explants obtained optimal number of shoots $(26 \pm 0.88 \mathrm{a})$ with shoot length (9.6 $\pm 0.30 \mathrm{a})$ on MS medium supplemented with BAP $\left(2 \mathrm{mg} \mathrm{l}^{-1}\right)$ and IAA $\left(0.5 \mathrm{mg} \mathrm{l}^{-1}\right)$. Half strength MS medium fortified with IBA $\left(2.0 \mathrm{mg} \mathrm{l}^{-1}\right)$ was effective and achieved $70 \%$ of rooting. These welldeveloped plantlets were shifted to pots containing soil and vermicompost in 1:1 ratio for acclimatization. The acclimatized plants were field transferred with survival rate of $85 \%$. The ISSR and RAPD markers analysis revealed the genetic stability of in vitro regenerated plants with the mother plant.
\end{abstract}

Keywords: genetic fidelity, ISSR, Muntingia calabura, RAPD, regeneration.

\section{Introduction}

Muntingia calabura $\mathrm{L}$. is a rapidly growing tree, domestic to the American continent, and is commonly cultivated in warm areas of the Asian region. The Muntingia calabura is also known locally as "Jamaican cherry", belongs to the Family Muntingiaceae. Muntingia calabura is regularly grown as roadside trees [MORTON, 1987; YUSOF \& al. 2011; ZAKARIA \& al. 2006a,b, 2007a-f, 2008, 2010, 2011]. The different plant parts of Muntingia calabura possess several potential medicinal uses in herbal medicine for the treatment as antiseptic [ZAKARIA \& al. 2006a], antipyretic [ZAKARIA \& al. 2007f], antiulcer [IBRAHIM \& al. 2012], antidiabetic [SRIDHAR \& al. 2011], antihypertensive [SHIH \& al. 2006], cardioprotective [NIVETHETHA \& al. 2009], anti-inflammatory, antinociceptive [ZAKARIA \& al. 2006a], antibacterial [YASUNAKA \& al. 2005] and antiplatelet aggregation [CHEN \& al. 2007], especially in leaves and roots. This plant is rich in flavonoids, flavones, and flavanones, rendering to its potent antitumor activities [KANEDA \& al. 1991]. Despite of its traditional claims, different parts of the plant have been used to treat various ailments. 
Muntingia calabura root extracts are screened for cytotoxic activities against A549 and HT-29 cells [KANEDA \& al. 1991]. Plant parts like leaves, roots, and stems were yielded cytotoxic flavonoids: Chrysin 2, 4-Dihydroxychalcone, and galanin 3, 7dimethyl ether. The boiled bark is used to reduce the swelling in the lower extremities [ZAKARIA \& al. 2006a]. Whereas, the leaves decoction or steeped water is employed to decrease ulcers in the stomach, prostate gland swelling and to alleviate headache and cold [MORTON, 1987]. The fruits are often cooked and made into jams. The Flowers are used as tranquilizers and tonic in Colombia [PEREZ-ARBEALAEZ, 1975].

There is a need to proliferate (or) multiply wider uses by conventional and biotechnological approaches. The improvement of the tree by traditional breeding is a delayed process due to its long juvenile period and high heterozygosity [SINGH \& al. 2002]. Micropropagation of tree species offers a renewable biomass, conserve the genetic traits and produce clonal saplings for afforestation [ROUT \& al. 2008]. Several plant species, especially woody plants are recalcitrant to high frequency root and shoot regeneration due to their in vitro recalcitrance [MCCOWN, 2000]. In vitro regeneration studies are difficult in woody tree species due to the high presence of phenols and alkaloids, which leads to the problem of browning callus. At the same time as, many of the researchers have established protocols in Gardenia latifolia Aiton, Elaeocarpus serratus L., etc. The present investigation was aimed for the development of sustainable regeneration protocol for Muntingia calabura and the influence of various plant growth regulators (PGRs) in the micropropagation. The regenerated plants were analyzed for genetic homogeneity studies using ISSR and RAPD markers. Moreover, the Muntingia calabura is growing at pollution releasing areas such as roadside and also heavy metal-containing areas. In future in vitro regenerated acclimatized plantlets can be used for isolating and screening of secondary metabolites from various plant parts and also these acclimatized plantlets roots are treated with bioinoculates (PGPR, Azotobacter, PSM and Mycorrhiza) for evaluating their survival rate in abiotic stress conditions.

\section{Material and methods}

Explants source and surface sterilization. The fruits of Muntingia calabura were squeezed and mixed in soil, later they were rubbed in sandy soil to separate the seeds. The seeds were used for the establishment of healthy plants in the polyhouse and field of Department of Biotechnology, Kakatiya University, Warangal, Telangana State, India. Young leaves, nodes, internodes, stem and other explants of Muntingia calabura were collected from the polyhouse or field during the month of January to December. The shoots were excised into $1.5 \mathrm{~cm}$ nodal segments and leaves were cut into $1 \mathrm{~cm}$ rectangular bits. Then the explants were washed rigorously under running tap water for 15-20 minutes for removing dust particles on the surface of explants. Then followed by surface sterilization by $1 \%$ Bavistin (a fungicide) solution for about 5 minutes and cleaned 3-4 times with sterilized double-distilled water. The explants are now transferred into laminar airflow for further sterilization. The explants (leaf and node segments) are now sterilized with $0.1 \%$ $(\mathrm{w} / \mathrm{v})$ mercuric chloride $\left(\mathrm{HgCl}_{2}\right)$ for about 2-3 minutes and then rinsed again with sterilized distilled water to remove any traces of $\mathrm{HgCl}_{2}$.

Culture medium and conditions. MS medium [MURASHIGE \& SKOOG, 1962] was prepared by adding $30 \mathrm{~g} / \mathrm{l}$ sucrose, $100 \mathrm{mg} / \mathrm{l}$ Myo-inositol and with varying concentrations of cytokinins BAP or kinetin $\mathrm{KN}\left(0.5-3 \mathrm{mg} \mathrm{l}^{-1}\right)$ and auxins IAA or NAA $\left(0.5 \mathrm{mg} \mathrm{l}^{-1}\right)$. The $\mathrm{pH}$ of 
the medium is set to $5.6 \pm 0.1$ with $1 \mathrm{~N} \mathrm{HCl}$ or $1 \mathrm{~N} \mathrm{NaOH}$ before the addition of agar $(0.8 \%)$. Now the culture media was sterilized in an autoclave with $1.1 \mathrm{~kg} \mathrm{~cm}^{-2}$ pressure at $121{ }^{\circ} \mathrm{C}$ for $15 \mathrm{~min}$. The surface sterilized explants were inoculated onto the sterilized culture medium (one explant per culture tube). All inoculated cultures were transferred into a controlled condition chamber for the incubation at $25 \pm 2{ }^{\circ} \mathrm{C}$ temperature with a relative humidity of $65 \pm 5 \%$ under a $2000-2500$ lux for $16 \mathrm{~h}$ Photoperiod. Data was collected and analyzed after a period of 45 days.

Callus induction and shoot proliferation. Initially after two weeks, brown and light green color callus was initiated from cut margins of leaf and node explants cultured on MS medium containing $0.5 \mathrm{mg} \mathrm{l}^{-1} 2,4-\mathrm{D}$. After the third week, the brown and thick green callus expunged was subcultured onto medium with $0.5 \mathrm{mg} \mathrm{l}^{-1}$ IAA or NAA with various concentrations of $\mathrm{KN}\left(0.5,1.0,1.5,2.0,2.5\right.$ and $\left.3 \mathrm{mg} \mathrm{l}^{-1}\right)$ or with BAP $(0.5,1.0,1.5,2.0$, 2.5 and $3 \mathrm{mg} \mathrm{l}^{-1}$ ) to identify the utmost appropriate combination of PGR's for the multiplication of regenerated shoots from leaf and node segment of Muntingia calabura. The data on percentage of regeneration, number of regenerated shoots per explants and their shoot length $(\mathrm{cm})$ was recorded after fourth week of culture.

Rooting of in vitro regenerated shoots. After achieving healthy and elongated in vitro regenerated shoots upto a height of 1.0 to $1.5 \mathrm{~cm}$, they are excised and cultured onto $0.8 \%$ agar-gelled with half strength MS medium fortified with various concentrations of IBA $0.5,1.0,1.5,2.0,2.5 \mathrm{mg} \mathrm{l}^{-1}$ for induction of in vitro rooting from regenerated shoots. The percentage of rooting, number of roots and their length $(\mathrm{cm})$ was recorded after fourth and fifth week of culture.

Hardening and acclimatization. The in vitro regenerated plantlets were carefully removed from the culture vessels and washed thoroughly with sterile distilled water to get rid of adhered agar and then transplanted into plastic cups filled with sterile garden soil and vermicompost (1:1) and maintained inside a plant growth chamber at $25 \pm 1^{\circ} \mathrm{C}$ under $16 \mathrm{hr}$ daylight provided by white fluorescent lamps. After acclimatization, these plantlets were transferred under greenhouse conditions and covered with polythene sheets for maintaining moisture and humidity for further acclimatization. After sixth and seventh weeks these acclimatized plants were hardened by transplanting into large pots filled with garden soil and manure. The percentage of survival was recorded after 3 weeks of the field transfer and found to be $85 \%$ same to the mother plant.

Genomic DNA Isolation and genetic homogeneity analysis. The genomic DNA was isolated from the mother plant and regenerated plantlets by using cetyltrimethyl ammonium bromide (CTAB) method [DOYLE \& DOYLE, 1990]. The DNA concentration was checked by $0.8 \%$ agarose gel electrophoresis. Assessment of genetic fidelity of Muntingia calabura plants was performed through Inter-Simple Sequence Repeats (ISSR) and Random Amplified Polymorphic DNA (RAPD) analysis. Each set of 10 ISSR and RAPD primers was selected for the genetic stability study. The PCR reaction mixtures and conditions are followed based on the protocol described by PENDLI \& al. (2019). The PCR bands were calculated using the 100 bp DNA ladder (Himedia). The experiments were repeated thrice to verify the reproducibility of PCR bands.

Data analysis and observations. The cultures were regularly subcultured onto fresh medium with an interval of 4-5 weeks. The cultures were observed and recorded after every six days of inoculation. All the experimental work was conducted thrice with 60 explants for each combination. The significant differences for various parameters recorded were calculated by mean and standard error variance (ANOVA) using SPSS software. 


\section{Results and discussions}

The sterilization treatments of explants with $0.1 \%(\mathrm{w} / \mathrm{v})$ mercuric chloride $\left(\mathrm{HgCl}_{2}\right)$ yielded $95 \%$ of contamination-free leaf and nodes of Muntingia calabura. The responses of both the explants inoculated shown the capacity of shoot regeneration differently to the two cytokinins (BAP and $\mathrm{KN}$ ) and combination with (IAA and NAA) with various concentrations of PGR's. The 15-day callus subcultured on MS modified medium showed efficient shoot induction. The age of explants showed to play a key role in morphogenesis [DISTABANJONG \& GENEVE, 1997].

Callus induction from leaf and node explants. Muntingia calabura is a woody tree species and contain a wide variety of secondary metabolites like alkaloids or phenols, the browning of the medium may be due to the production of alkaloids or phenols in the medium. The mixture of antioxidant was found to reduce the phenolic exudation and browning of callus in Ceratonia siliqua, Pterocarpus santalinus [ROMANO \& al. 2002; PRAKASH \& al. 2006]. Callus was induced from the excised portions of midrib and lateral veins of leaf lamina and basal part of nodal regions of the node. The initiation of callus was achieved even at lower concentrations of auxin alone with $0.5 \mathrm{mg} \mathrm{l}^{-1} 2,4-\mathrm{D}$. 2,4-D found to be good in inducing callus from leaf and nodal explants (Figure 1a and Figure 2a). 2,4-D plays a major role in callus induction in an ample range [RANI \& GROVER, 1999]. An identical report on high percentage of callus induction was obtained from stem and leaf explants on MS medium with IAA $\left(0.5 \mathrm{mg} \mathrm{l}^{-1}\right)$ and 2,4-D (1.0 $\left.\mathrm{mg} \mathrm{l}^{-1}\right)$ in Citrullus colocynthis [SHASTHREE \& al. 2012] and Momordica cymbalaria [CHAITANYA \& al. 2020]. A problem of browning callus in the node segment (Figure 2a) and blackish light green color callus in leaf (Figure 1a) explant was observed during the initiation of callus from Muntingia calabura. Acacia auriculiformis, Strelitzia reginae, and Anemone coronaria have also been reported that this problem can be prevented by adding up of activated charcoal (AC) to the medium which discolors and stimulates the shoot growth [YADAV \& al. 2016]. Whereas the present work promoted by frequent subculturing of explants for every 10-20 days to reduce the browning of callus and the growth of callus kept increased.

Indirect regeneration studies from leaf explants. Regeneration of high number of shoots of Muntingia calabura with proper growth was achieved by testing varying combination of cytokinins (BAP and KN) with auxins (IAA and NAA). In leaf explants, 2 to 4 micro shoots were initiated from second week's brown or coffee colored callus (Figure 1b). After third-week brown colored callus slowly changed to green colored callus and few shoots formation was occurred simultaneously (Figure 1c). The leaf explants exhibited a highest shoot regeneration of $60 \%$ when cultured on multiplication medium with BAP (2.0 $\mathrm{mg} \mathrm{l}^{-1}$ ) or $\mathrm{KN}\left(2.0 \mathrm{mg} \mathrm{l}^{-1}\right)$ in combination with $0.5 \mathrm{mg} \mathrm{l}^{-1}$ IAA or $0.5 \mathrm{mg} \mathrm{l}^{-1} \mathrm{NAA}$. The explants inoculated onto the medium containing a low level of auxin and cytokinin have shown their response by early enlargement of nodes with axillary bud break within 25 days (Figure 1d). The proliferated shoot buds are shifted to a medium where the concentration of cytokinin is kept increased and the auxin concentration was maintained constant (Figure $1 \mathrm{e})$. The number of shoots developed from leaf explants ranged from $13 \pm 0.3 \mathrm{~h}$ to $32 \pm 0.8 \mathrm{a}$ on medium fortified with $2.0 \mathrm{mg} \mathrm{l}^{-1} \mathrm{BAP}+0.5 \mathrm{mg} \mathrm{l}^{-1}$ IAA (Figure 1f). The highest shoot length was found to be $7.6 \pm 0.1 \mathrm{a}$ on BAP $\left(2 \mathrm{mg} \mathrm{l}^{-1}\right)$ and IAA $\left(0.5 \mathrm{mg} \mathrm{l}^{-1}\right)$ MS medium (Figure $1 \mathrm{~g}$ and $1 \mathrm{~h})$. The synergistic effect of BAP with IAA on shoot elongation has also reported in Acacia auriculiformis [YADAV \& al. 2016]. An average of $4 \pm 06 \mathrm{j}$ to $30 \pm 0.6 \mathrm{~b}$ (Table 1 ) 
number of shoots were obtained on medium containing $2.5 \mathrm{mg} \mathrm{l}^{-1} \mathrm{KN}$ with $0.5 \mathrm{mg} \mathrm{l}^{-1} \mathrm{IAA}$ and $1 \pm 0.5 \mathrm{k}$ to $24 \pm 0.1 \mathrm{e}$ (Table 1) with $2.0 \mathrm{mg} \mathrm{l}^{-1} \mathrm{KN}$ and $0.5 \mathrm{mg} \mathrm{l}^{-1} \mathrm{NAA}$ in leaf explants. Excellent high frequency regeneration of Populus deltoides, a hardwood tree was also reported in combination of KN and IAA [YADAV\& al. 2009]. Whereas, in Gardenia latifolia BA (4.0 $\left.\mathrm{mg} \mathrm{l}^{-1}\right)$ and IAA $\left(0.5 \mathrm{mg} \mathrm{l}^{-1}\right)$ had the best results for shoot regeneration from leaf [REDDY \& SARITHA, 2013]. The hostile effect of cytokinin percentage in shoot induction decreases as the concentration of cytokinin increases. This effect has also been reported in Pterocarpus marsupium [ANIS \& al. 2005]. The BAP is more efficient and more energetic cytokinin in many tree species like Syzygium alternifolium [SHA VALLI KHAN \& al. 1999] and Pterocarpus marsupium [CHAND \& SINGH, 2004]. Decisively, the combination of auxins and cytokinins in the medium can improve organogenesis and regeneration of the cultured explants.
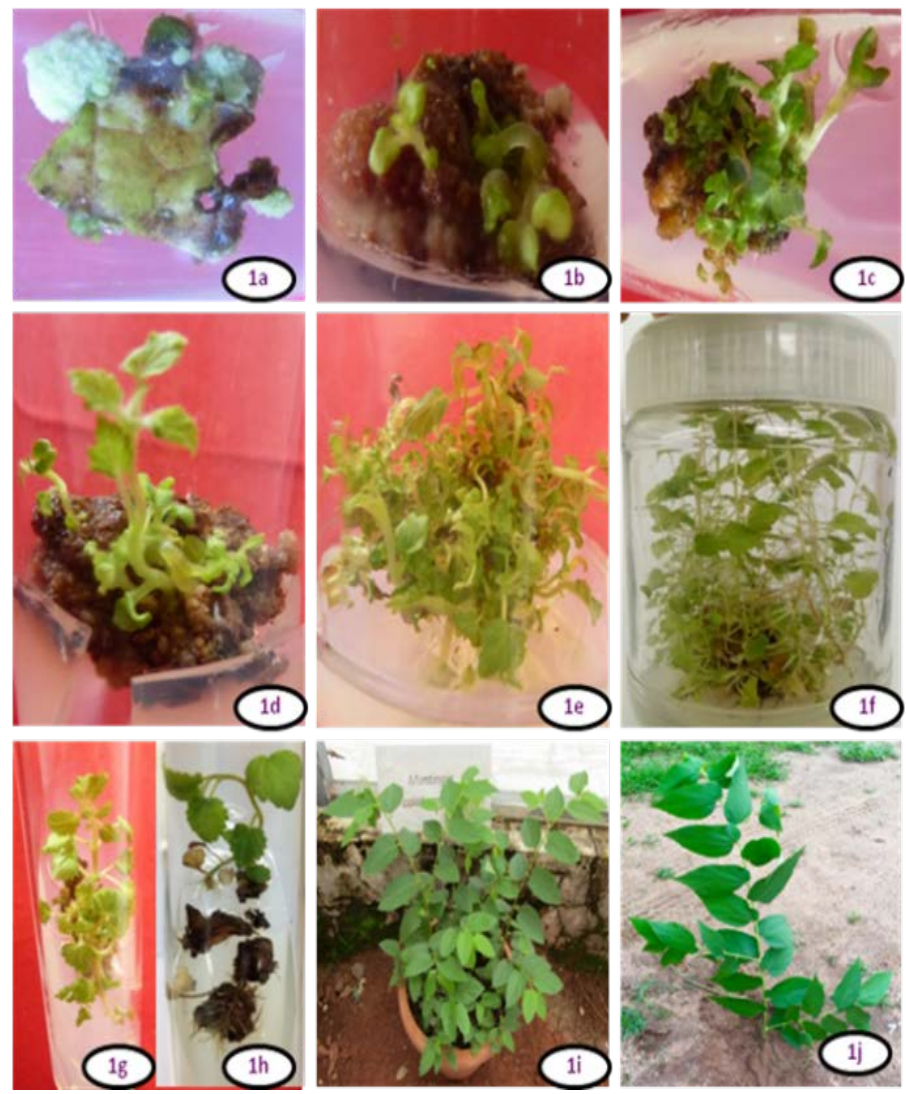

Figure 1. Effect of PGRs on indirect plant regeneration from leaf explants: a - Initiation of callus on 2,4-D at $0.5 \mathrm{mg} \mathrm{l}^{-1}$; b - Initiation of shoots in combination with $0.5 \mathrm{mg} \mathrm{l}^{-1} \mathrm{BAP}+\mathrm{IAA} 0.5 \mathrm{mg} \mathrm{l}^{-1}$; c - Proliferation of micro-shoots at $0.5 \mathrm{mg} \mathrm{l}^{-1} \mathrm{IAA}+$ BAP $1.0 \mathrm{mg} \mathrm{l}^{-1} ; \mathrm{d}$ - Elongation of shoots at 0.5 $\mathrm{mg} \mathrm{l}^{-1}$ IAA + $1.0 \mathrm{mg} \mathrm{l}^{-1} \mathrm{BAP}$; e - Formation of multiple shoot clusters on $0.5 \mathrm{mg} \mathrm{l}^{-1}+\mathrm{IAA}+1.5 \mathrm{mg} \mathrm{l}^{-1}$ BAP; f - High frequency of multiple shoots formed on $2 \mathrm{mg} \mathrm{l}^{-1}$; g \& $\mathrm{h}-$ Elongation of shoot with roots at alone IBA $2.0 \mathrm{mg} \mathrm{l}^{-1} ; \mathrm{i}$ - Partially hardened plant in an earthen pot containing 1:1 vermiculite inside the greenhouse; $\mathrm{j}$ - Green house grown plants transferred into field. 
MICROPROPAGATION OF MUNTINGIA CALABURA L. AND ASSESSMENT OF GENETIC...

Table 1. Effect of different concentrations of PGR's on multiple shoot induction using leaf and node explants of Muntingia calabura L. - a pharmaceutically and medicinally important woody tree.

\begin{tabular}{|c|c|c|c|c|c|c|c|c|c|}
\hline \multicolumn{3}{|c|}{$\begin{array}{c}\text { PGR'S and } \\
\text { Concentration }\end{array}$} & \multicolumn{2}{l}{ Regeneration } & \multicolumn{2}{c|}{ No. of shoots } & \multicolumn{2}{c|}{ Shoot length(cm) } \\
\hline BAP & KN & IAA & NAA & Leaf & Node & Leaf & Node & Leaf & Node \\
\hline 0.5 & & 0.5 & & 67 & 61 & $13 \pm 0.3 \mathrm{~h}$ & $16 \pm 0.5 \mathrm{cde}$ & $1.5 \pm 0.2 \mathrm{~h}$ & $1.7 \pm 0.1 \mathrm{~g}$ \\
\hline 1 & & 0.5 & & 70 & 68 & $23 \pm 0.5 \mathrm{e}$ & $16 \pm 0.8 \mathrm{cde}$ & $2.8 \pm 0.1 \mathrm{fg}$ & $3.7 \pm 0.1 \mathrm{~d}$ \\
\hline 1.5 & & 0.5 & & 77 & 71 & $27 \pm 0.1 \mathrm{c}$ & $20 \pm 0.4 \mathrm{~b}$ & $6.4 \pm 0.3 \mathrm{~b}$ & $9.3 \pm 0.4 \mathrm{a}$ \\
\hline 2 & & 0.5 & & 93 & 88 & $32 \pm 0.8 \mathrm{a}$ & $26 \pm 0.8 \mathrm{a}$ & $7.6 \pm 0.1 \mathrm{a}$ & $9.6 \pm 0.3 \mathrm{a}$ \\
\hline 2.5 & & 0.5 & & 84 & 80 & $24 \pm 0.7 \mathrm{de}$ & $18 \pm 0.6 \mathrm{~b}$ & $5.5 \pm 0.4 \mathrm{c}$ & $6.9 \pm 0.3 \mathrm{~b}$ \\
\hline 3 & & 0.5 & & 67 & 76 & $18 \pm 0.8 \mathrm{f}$ & $10 \pm 0.1 \mathrm{gh}$ & $3.0 \pm 0.3 \mathrm{ef}$ & $3.6 \pm 0.2 \mathrm{de}$ \\
\hline & 0.5 & 0.5 & & 46 & 40 & $4 \pm 0.6 \mathrm{j}$ & $2 \pm 0.2 \mathrm{jkl}$ & $0.5 \pm 0.2 \mathrm{i}$ & $0.1 \pm 0.1 \mathrm{i}$ \\
\hline & 1 & 0.5 & & 55 & 48 & $10 \pm 0.4 \mathrm{i}$ & $8 \pm 0.3 \mathrm{hi}$ & $1.4 \pm 0.3 \mathrm{~h}$ & $1 \pm 0.2 \mathrm{hi}$ \\
\hline & 1.5 & 0.5 & & 55 & 50 & $23 \pm 0.5 \mathrm{e}$ & $14 \pm 0.8 \mathrm{f}$ & $5.1 \pm 0.4 \mathrm{~d}$ & $3.2 \pm 0.4 \mathrm{def}$ \\
\hline & 2 & 0.5 & & 62 & 58 & $25 \pm 0.5 \mathrm{cde}$ & $17 \pm 0.5 \mathrm{~cd}$ & $5.5 \pm 0.3 \mathrm{~cd}$ & $5.4 \pm 0.2 \mathrm{c}$ \\
\hline & 2.5 & 0.5 & & 70 & 66 & $30 \pm 0.6 \mathrm{~b}$ & $25 \pm 0.6 \mathrm{a}$ & $7.5 \pm 0.5 \mathrm{a}$ & $6.3 \pm 0.3 \mathrm{~b}$ \\
\hline & 3 & 0.5 & & 68 & 58 & $25 \pm 0.8 \mathrm{cde}$ & $16 \pm 0.4 \mathrm{cdef}$ & $7.5 \pm 0.2 \mathrm{a}$ & $3.5 \pm 0.2 \mathrm{def}$ \\
\hline 0.5 & & & 0.5 & 54 & 58 & $4 \pm 0.5 \mathrm{j}$ & $1 \pm 0.3 \mathrm{l}$ & $1.6 \pm 0.2 \mathrm{~h}$ & $0.5 \pm 0.2 \mathrm{hi}$ \\
\hline 1 & & & 0.5 & 67 & 60 & $10 \pm 0.5 \mathrm{i}$ & $3 \pm 0.1 \mathrm{jk}$ & $3.6 \pm 0.2 \mathrm{e}$ & $1.5 \pm 0.2 \mathrm{~g}$ \\
\hline 1.5 & & & 0.5 & 77 & 69 & $15 \pm 0.3 \mathrm{gh}$ & $9 \pm 0.5 \mathrm{ghi}$ & $3.6 \pm 0.2 \mathrm{e}$ & $2.6 \pm 0.1 \mathrm{f}$ \\
\hline 2 & & & 0.5 & 80 & 75 & $26 \pm 0.2 \mathrm{~d}$ & $17 \pm 0.8 \mathrm{~cd}$ & $6.4 \pm 0.4 \mathrm{~b}$ & $3.6 \pm 0.2 \mathrm{ef}$ \\
\hline 2.5 & & & 0.5 & 78 & 64 & $16 \pm 0.2 \mathrm{~g}$ & $11 \pm 0.5 \mathrm{~b}$ & $2.4 \pm 0.3 \mathrm{f}$ & $3.2 \pm 0.4 \mathrm{def}$ \\
\hline 3 & & & 0.5 & 60 & 50 & $10 \pm 0.4 \mathrm{i}$ & $7 \pm 0.33 \mathrm{i}$ & $1.5 \pm 0.2 \mathrm{~h}$ & $0.9 \pm 0.05 \mathrm{i}$ \\
\hline & 0.5 & & 0.5 & 57 & 46 & $1 \pm 0.5 \mathrm{k}$ & $0.6 \pm 0.33 \mathrm{l}$ & $0.5 \pm 0.2 \mathrm{i}$ & $0.2 \pm 0.2 \mathrm{i}$ \\
\hline & 1 & & 0.5 & 66 & 60 & $5 \pm 0.5 \mathrm{j}$ & $2 \pm 0.2 \mathrm{jkl}$ & $2.0 \pm 0.2 \mathrm{f}$ & $0.5 \pm 0.2 \mathrm{hi}$ \\
\hline & 1.5 & & 0.5 & 70 & 55 & $19 \pm 0.6 \mathrm{f}$ & $10 \pm 0.6 \mathrm{gh}$ & $2.7 \pm 0.1 \mathrm{ef}$ & $0.5 \pm 0.2 \mathrm{hi}$ \\
\hline & 2 & & 0.5 & 75 & 64 & $24 \pm 0.1 \mathrm{de}$ & $15 \pm 0.5 \mathrm{ef}$ & $5.1 \pm 0.4 \mathrm{c}$ & $2.7 \pm 0.1 \mathrm{ef}$ \\
\hline & 2.5 & & 0.5 & 66 & 52 & $16 \pm 0.2 \mathrm{~g}$ & $9 \pm 0.3 \mathrm{ghi}$ & $4.7 \pm 0.1 \mathrm{~d}$ & $2.7 \pm 0.1 \mathrm{ef}$ \\
\hline & 3 & & 0.5 & 56 & 45 & $8 \pm 0.33 \mathrm{i}$ & $3 \pm 0.5 \mathrm{j}$ & $1.8 \pm 0.1 \mathrm{~h}$ & $1.3 \pm 0.4 \mathrm{~g}$ \\
\hline
\end{tabular}

Direct regeneration studies from node explants. Development of new axillary shoots on medium with varying concentrations of BAP or $\mathrm{KN}$ in addition to IAA $\left(0.5 \mathrm{mg} \mathrm{l}^{-1}\right)$ and NAA $\left(0.5 \mathrm{mg} \mathrm{l}^{-1}\right)$ has revealed that BAP is efficient over $\mathrm{KN}$ in all the combinations. The combination of BAP $2 \mathrm{mg} \mathrm{l}^{-1}+$ IAA $0.5 \mathrm{mg} \mathrm{l}^{-1}$ is found to be efficient for shoot bud elongation in node than in leaf (Figure 2c). Similarly, the regeneration of the node had shown less response compared to leaf with BAP $2 \mathrm{mg} \mathrm{l}^{-1}$ in combination with NAA $0.5 \mathrm{mg}$ $\mathrm{l}^{-1}$ and IAA $0.5 \mathrm{mg} \mathrm{l}^{-1}$. Node explants showed maximum number of shoots from $16 \pm 0.5 \mathrm{cde}$ to $26 \pm 0.8 \mathrm{a}$ on BAP $2 \mathrm{mg} \mathrm{l}^{-1}+$ IAA $0.5 \mathrm{mg} \mathrm{l}^{-1}$ and from $1 \pm 0.3 \mathrm{i}$ to $17 \pm 0.8 \mathrm{~cd}$ on BAP $2 \mathrm{mg} \mathrm{l}^{-1}$ + NAA $0.5 \mathrm{mg} \mathrm{l}^{-1}$ (Figure 2d and Table 1) and the highest shoot length of $9.6 \pm 0.3 \mathrm{a}$ was also developed on BAP $2 \mathrm{mg} \mathrm{l}^{-1}+$ IAA $0.5 \mathrm{mg} \mathrm{l}^{-1}$. In nodal explants a range of $2 \pm 0.2 \mathrm{jkl}$ to $25 \pm 0.6$ a (Figure 2e and Table 1 ) mean number of shoots was noticed on medium with KN $2.5 \mathrm{mg} \mathrm{l}^{-1}$ and IAA $0.5 \mathrm{mg} \mathrm{l}^{-1}$ whereas $0.6 \pm 0.33 \mathrm{i}$ to $15 \pm 0.5 \mathrm{ef}$ number of shoots were developed with KN $2.0 \mathrm{mg} \mathrm{l}^{-1}+$ NAA $0.5 \mathrm{mg} \mathrm{l}^{-1} \mathrm{~g} / \mathrm{l}$ after 6 weeks. In Artemisia nilagirica, a high regeneration frequency occurred when nodal explants were cultured on MS medium with $2.5 \mathrm{mg} \mathrm{l}^{-1}$ BAP and $7.5 \mathrm{mg} \mathrm{l}^{-1}$ 2-iP [SHINDE \& al. 2016]. In Elaeocarpus family, the species Elaeocarpus sphaericus and Elaeocarpus robustus an efficient micropropagation method using $\mathrm{BA}+\mathrm{KN}+$ casein hydrolysate was reported from node explants. The best 
results for shoot induction was reported in Elaeocarpus sphaericus [SAKLANI \& al. 2015, LAKSHMI \& al. 2010] on MS+2.2 $\mu \mathrm{M} \mathrm{BA}+2.2 \mu \mathrm{M} \mathrm{KN}$, whereas with equal concentrations of BA + KN + casein hydrolysate in Elaeocarpus robustus [ROY \& al. 1998]. ARSHAD \& KUMAR (2006) have also developed a protocol using axillary buds of Elaeocarpus tuberculatus on MS medium containing equal concentrations of only cytokinins in the combination of BA and $\mathrm{KN}$.
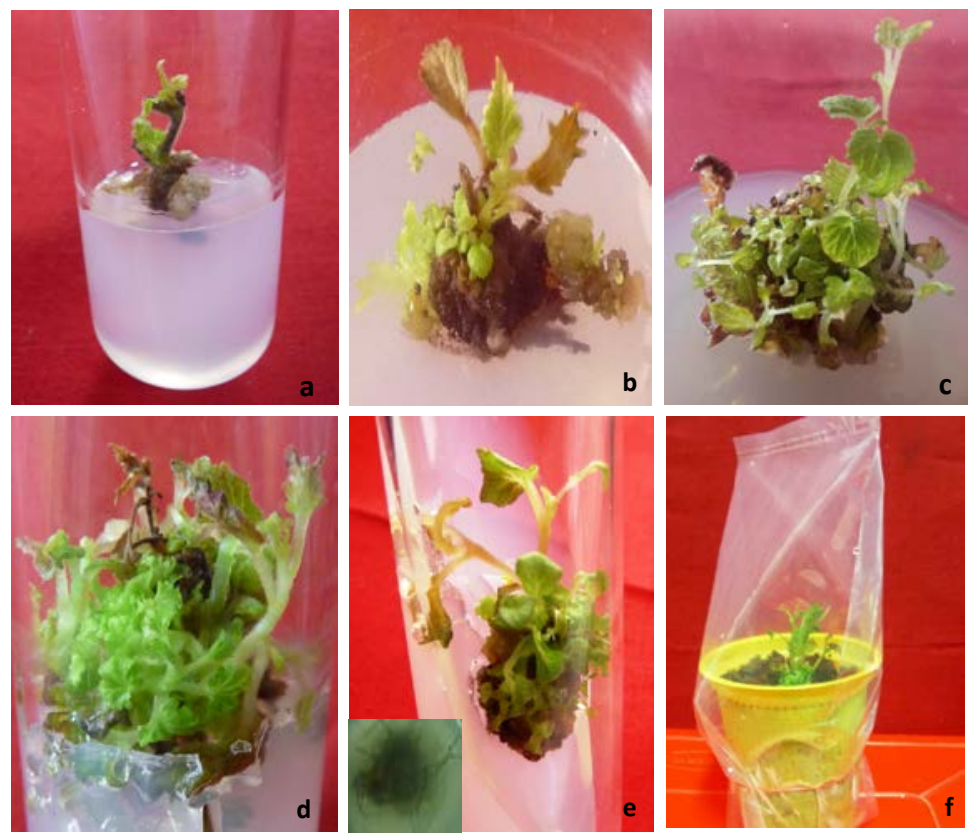

Figure 2. Effect of PGRs on direct regeneration from node explants: a - initiation of callus from mature nodal explants on MS medium with $0.5 \mathrm{mg} \mathrm{l}^{-1} 2,4-\mathrm{D}$; $\mathrm{b}$ - proliferation of shoots from nodal brown calli on MS medium with $1.0 \mathrm{mg} \mathrm{l}^{-1} \mathrm{BAP}+0.5 \mathrm{mg} \mathrm{l}^{-1} \mathrm{IAA}$; c - elongation of multiple shoots with $1.5 \mathrm{mg} \mathrm{l}^{-1}$ BAP + $0.5 \mathrm{mg} \mathrm{l}^{-1}$ IAA; d - elongation of multiple shoots with $2.0 \mathrm{mg} \mathrm{l}^{-1} \mathrm{BAP}+0.5 \mathrm{mg} \mathrm{l}^{-1}$ IAA; $\mathrm{e}-$ formation of roots from the lower part of the in vitro shoots on MS medium containing $2.0 \mathrm{mg} \mathrm{l}^{-1}$ IBA; $\mathrm{f}$ - in vitro regenerated plantlets transferred to plastic cup possessing soil and vermicompost (1:1) and the plantlets covered with polythene sheet for acclimatization.

Rooting for in vitro shoots. Individual shoots were excised and inoculated onto half-strength MS medium containing IBA. IBA at a concentration of $2.0 \mathrm{mg} \mathrm{l}^{-1}$ induced rooting with a root length of $2 \pm 0.33$ b with maximum $25 \pm 0.57$ a (Figure 2e-r and Table 2) number of roots. But the maximum root length of $3 \pm 0.3$ a was observed at IBA $2.5 \mathrm{mg} \mathrm{l}^{-1}$. At lower concentrations of IBA, the number of roots grown was less comparatively at 2.0 $\mathrm{mg} \mathrm{l}^{-1}$. Interestingly, as the concentration of IBA is increased above $2 \mathrm{mg} \mathrm{l}^{-1}$ basal callusing was observed all through the surface of shoots and there was also a decrease in root length. IBA has been identified to induce the best rooting response in woody tree species. Similar reports were observed in Gardenia latifolia with IBA at $4.0 \mathrm{mg} \mathrm{l}^{-1}$ of concentration on halfstrength MS medium [REDDY \& SARITHA, 2013]. 
Table 2. Effect of different concentrations of IBA on rooting of in vitro regenerated shoots of Muntingia calabura after 6 weeks $1 / 2$ strength MS medium.

\begin{tabular}{|c|c|c|c|}
\hline Auxin IBA & \% of rooting & Root number & Root length (cm) \\
\hline 0.5 & 20 & $5 \pm 0.33 \mathrm{e}$ & $0.2 \pm 0.3 \mathrm{~d}$ \\
\hline 1.0 & 39 & $12 \pm 0.57 \mathrm{~d}$ & $0.5 \pm 0.3 \mathrm{~cd}$ \\
\hline 1.5 & 55 & $18 \pm 0.33 \mathrm{c}$ & $1 \pm 0 \mathrm{c}$ \\
\hline 2.0 & 60 & $25 \pm 0.57 \mathrm{a}$ & $2 \pm 0.2 \mathrm{~b}$ \\
\hline 2.5 & 51 & $21 \pm 0.57 \mathrm{~b}$ & $3 \pm 0.3 \mathrm{a}$ \\
\hline
\end{tabular}

Hardening and acclimatization. In vitro grown complete plantlets of Muntingia calabura are carefully taken out and washed gently to remove the adhered media. Polythene cups containing garden soil and vermicompost in 1:1 ratio was found to be best for hardening (Figure 2f). Hardened plantlets were maintained initially in greenhouse conditions by irrigating with MS salt solution (half-strength) for four weeks (Figure 1i). The poly cups with hardened plantlets were covered with polythene sheets and proper watering was done to maintain humidity (50-70\%) and moisture. Later, plantlets were planted and acclimatized in field conditions with high survivability of $85 \%$ was observed (Figure 1j).

Genetic fidelity analysis. The ISSR and RAPD markers were employed to identify the genetic fidelity of the mother plant and the regenerated plants of Muntingia calabura. Earlier reports suggested that using of more than one type of molecular marker in genetic homogeneity studies of in vitro regenerated plants is always useful for reliability [ROHELA \& al. 2019]. In the current investigation, ISSR (10) and RAPD (10) primers (Table 3 \& Table 4) were used for the screening of genetic homogeneity of in vitro regenerated plants with the parent plant. In out of 10 ISSR primers, seven primers were produced reproducible and clear bands, the PCR banding pattern of MC4 primer shown in Figure 3. In out of 10 RAPD-primers, six primers were amplified with scorable and clear reproducible bands, the PCR banding profile of OPA6 shown in Figure 4. ISSR and RAPD analysis confirmed that there is no polymorphic nature in regenerated and mother plants; both plants exhibited similar monomorphic banding patterns. Therefore, the results prove that the mother plant and regenerated plant contains the same gene pool (Figure 3, 4). A similar kind of genetic fidelity evaluation using ISSR and RAPD markers was successfully achieved in different plant systems like Rauwolfia tetraphylla [ROHELA \& al. 2019], Citrullus colocynthis [RAMAKRISHNA \& al. 2012], Solanum trilobatum [PENDLI \& al. 2019], and Flemingia macrophylla [SIRIKONDA \& al. 2020]. 
Suvarchala VANKUDOTH \& al.

Table 3. List of ISSR and RAPD primers used in genetic fidelity analysis of Muntingia calabura L. - a pharmaceutically and medicinally important woody tree.

\begin{tabular}{|c|c|l|c|c|l|}
\hline \multicolumn{2}{|c|}{ ISSR } & \multicolumn{3}{c|}{ RAPD } \\
\hline s.No. & Primer code & \multicolumn{1}{|c|}{ Primer sequence (5' -3') $^{\prime}$ S.No. } & Primer code & Primer sequence (5'-3') \\
\hline 1 & MC1 & TCTCTCTCTCTCTCTCC & 1 & OPA1 & TGGGCGTCAA \\
\hline 2 & MC2 & TCTCTCTCTCTCTCTCG & 2 & OPA2 & CAGGCCCTTC \\
\hline 3 & MC3 & AGAGAGAGAGAGAGAGC & 3 & OPA3 & GGCATGACCT \\
\hline 4 & MC4 & AGAGAGAGAGAGAGAGG & 4 & OPA4 & GGGTAACGCC \\
\hline 5 & MC5 & GAGAGAGAGAGAGAGAC & 5 & OPA5 & CCAGCAGCTT \\
\hline 6 & MC6 & GAGAGAGAGAGAGAGAT & 6 & OPA6 & AGTCAGCCAC \\
\hline 7 & MC7 & GAGAGAGAGAGAGAGAYT & 7 & OPA7 & TGCCGAGCTG \\
\hline 8 & MC8 & AGAGAGAGAGAGAGAGYT & 8 & OPA8 & AATCGGGCTG \\
\hline 9 & MC9 & GAGAGAGAGAGAGAGAYG & 9 & OPA9 & GACTGCACAC \\
\hline 10 & MC10 & AGAGAGAGAGAGAGAGTC & 10 & OPA10 & AGGGGTCTTG \\
\hline
\end{tabular}

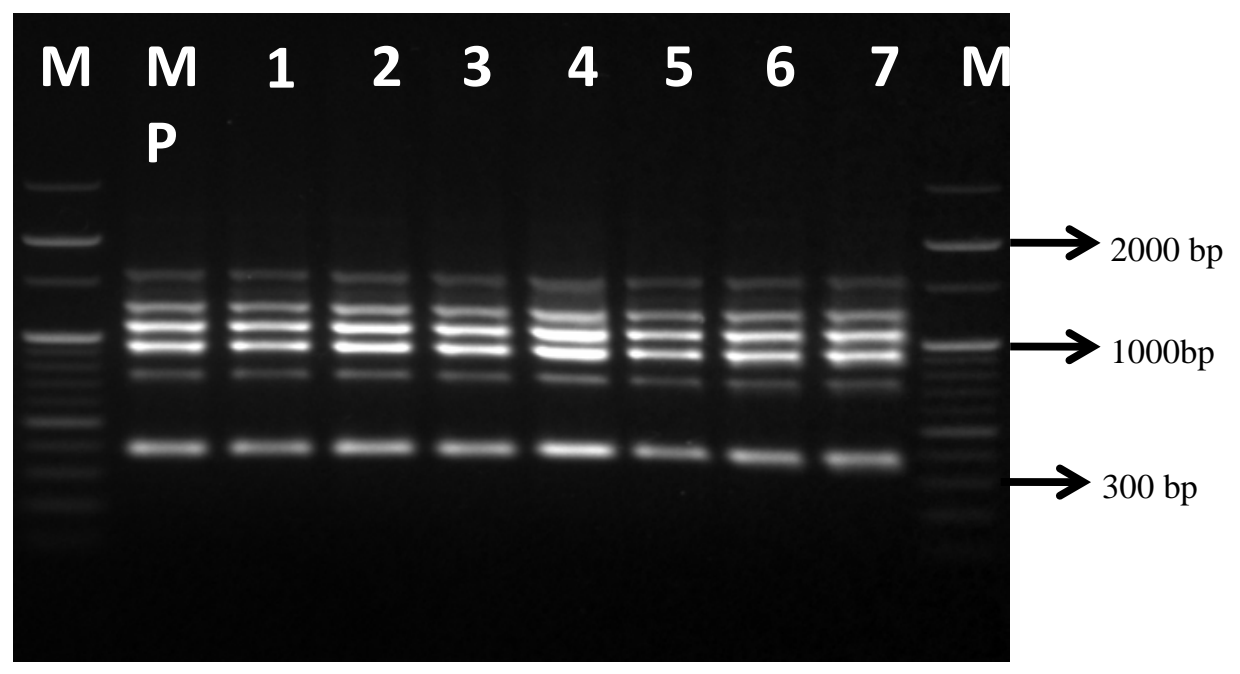

Figure 3. PCR banding profile of ISSR based genetic fidelity analysis of Muntingia calabura amplified with MC4 primer. Lane M: 100 bp DNA ladder (Himedia, India). Lane MP: PCR banding pattern of mother plant. Lane 1-7: PCR banding pattern of regenerated plants. 


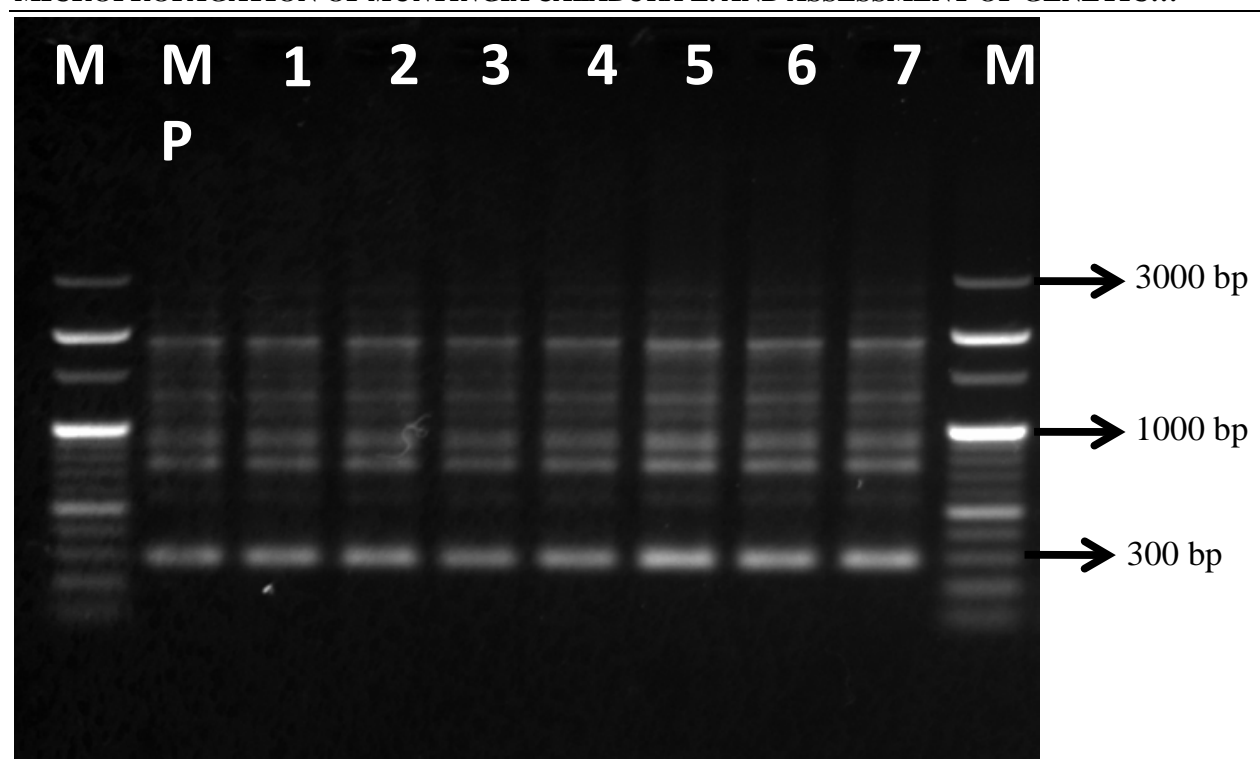

Figure 4. PCR banding profile of RAPD based genetic fidelity analysis of Muntingia calabura amplified with OPA6 primer. Lane M: 100 bp DNA ladder (Himedia, India). Lane MP: PCR banding pattern of mother plant. Lane 1-7: PCR banding pattern of regenerated plants.

\section{Conclusions}

The present investigation appears to be the first report on regeneration studies of medicinally important woody tree Muntingia calabura and assessment of genetic fidelity demonstrates the true-to-type nature of regenerated plants comparatively to the mother plant. Our research findings established the protocol of regeneration studies in the woody tree using PGRs at lower concentrations with eradicating the problem of browning callus without using any anti-browning agents through regular subculturing of cultures. The highest number of shoots was observed to be 32 $\pm 0.8 \mathrm{a}$ in leaf explants on MS medium along with BAP $2.0 \mathrm{mg} \mathrm{l}^{-1}+$ IAA $0.5 \mathrm{mg} \mathrm{l}^{-1}$ and $26 \pm 0.8 \mathrm{a}$ in node explants on BAP $2.0 \mathrm{mg} \mathrm{l}^{-1}+$ IAA $0.5 \mathrm{mg} \mathrm{l}^{-1}$. The highest rooting frequency is $25 \pm 0.57$ a was obtained on IBA $2.0 \mathrm{mg} \mathrm{l}^{-1}$. The regeneration in leaf and node explants cultured on to MS medium with BAP or KN in combination with IAA and NAA exposed that BAP is more efficient to $\mathrm{KN}$ in all tried combinations. BAP has given the maximum efficiency of shoots comparative to KN, with the addition of IAA produced a high organogenic response of the explants. Further, in vitro regenerated acclimatized plantlets are using for isolating and screening of secondary metabolites from various plant parts. For the above reasons, the biotechnological analysis studies are required in Muntingia calabura. 
Suvarchala VANKUDOTH \& al.

\section{Notes on contributors}

Suvarchala VANKUDOTH is PhD student and she has conducted the total experimental work. Ramakrishna DASARI is a research scientist and expert in plant tissue culture and Biotechnology.

Pavani CHIRUMAMILLA is a PhD student and she has conducted the total experimental work.

Chaitanya GOPU is also a PhD student and she has designed the figures and tables.

Phanikanth JOGAM is a $\mathrm{PhD}$ completed student and he has conducted genetic fidelity study.

Srinivas KOTA is a PhD student and he has edited the whole manuscript.

Shasthree TADURI is a senior grade professor and plant biotechnologist. His work focuses on developing regeneration protocols for the medicinal and endangered plants. His research group is actively involving in isolation, screenings, and enhancement of bioactive compounds using biotic and abiotic elicitors. Shasthree TADURI availed Dr. CV Raman Fellowship in Mississippi State University, USA and Associated fellow of Telangana Academy of Sciences. He also attended and presented his research findings in national and international conferences.

\section{Acknowledgements}

The first author gratefully acknowledges the National fellowship for Higher Education (NFST-2015-17-ST-TEL-2837) for providing financial assistance.

\section{References}

ANIS M., HUSAIN M. K. \& SHAHZAD A. 2005. In vitro plantlet regeneration of Pterocarpus marsupium Roxb. An endangered leguminous tree. Current Science. 88: 861-863.

ARSHAD S. M. \& KUMAR A. 2006. Tissue culture investigation of Elaeocarpus tuberculatus-a highly valued rudraksha. Vegetos-An International Journal of Plant Research. 19: 111-114.

CHAND S. \& SINGH A. K. 2004. In vitro shoot regeneration from cotyledonary node explants of a multipurpose leguminous tree, Pterocarpus marsupium Roxb. In Vitro Cellular \& Developmental Biology-Plant. 40: 464-466. https://doi.org/10.1079/IVP2004548

CHAITANYA G., SUVARCHALA V., RAMAKRISHNA D., SUNITHA D. \& SHASTHREE T. 2020. In vitro plant regeneration of Momordica cymbalaria Fenzl. and assessment of genetic fidelity using ISSR primers. Research Journal of Biotechnology. 15: 103-110.

CHEN J. J., LEE H. H., SHIH C. D., LIAO C. H., CHEN I. S. \& CHOU T. H. 2007. New dihydrochalcones and anti-platelet aggregation constituents from the leaves of Muntingia calabura. Planta Medica. 73: 572577. https://doi.org/10.1055/s-2007-967196

DISTABANJONG K. \& GENEVE R. L. 1997. Multiple shoot formation from cotyledonary node segments of Eastern redbud. Plant Cell, Tissue and Organ Culture. 47: 247-254. https://doi.org/10.1007/BF02318979

DOYLE J. J. \& DOYLE J. L. 1990. Isolation of plant DNA from fresh tissue. Focus. 12: 13-15.

IBRAHIM I. A. A., ABDULLA M. A., ABDELWAHAB S. I., BAYATY F. \& MAJID N. A. 2012. Leaves extract of Muntingia calabura protects against gastric ulcer induced by ethanol in Sprague-Dawley rats. Journal of Clinical and Experimental Pharmacology. 55: 004. https://doi.org/10.4172/2161-1459.S5-004

KANEDA N., PEZZUTO J. M., SOEJARTO D. D., DOUGLAS KINGHORN A. \& FARNSWORTH N. R. 1991. Plant anticancer agents, XLVI New cytotoxic flavanoids from Muntingia calabura roots. Journal of Natural Products. 54: 196-206. https://doi.org/10.1021/np50073a019

LAKSHMI S. R., BENJAMIN J. F., KUMAR T. S., MURTHY G. V. S. \& RAO M. V. 2010. In vitro propagation of Hoya wightii ssp. palniensis K.T. Mathew, a highly vulnerable and endemic species of Western Ghats of Tamil Nadu, India. African Journal of Biotechnology. 9(5): 620-627. https://doi.org/10.5897/AJB09.846

MCCOWN B. H. 2000. Recalcitrance of woody and herbaceous perennial plants: Dealing with genetic predetermination. In Vitro Cellular \& Developmental Biology-Plant. 36: 149-154. https://doi.org/10.1007/s11627-000-0030-6

MORTON J. F. 1987. Jamaica cherry. In: MORTON J. F. (ed.). 1987. Fruits of Warm Climates, Vol. 2. Miami (FL): Timber Press. 2: 65-69.

MURASHIGE T. \& SKOOG F. 1962. A revised medium for rapid growth and bioassays with tobacco tissue cultures. Physiologia Plantarum. 15: 473-497.

NIVETHETHA M., JAYASARI J. \& BRINDHA P. 2009. Effects of Muntingia calabura L. on isoproterenolinduced myocardial infarction. Singapore Medical Journal. 50: 300-302. 

vitro plantlet regeneration in Solanum trilobatum L., an important ethno-medicinal plant and confirmation of genetic fidelity of R 1 plantlets by using ISSR and RAPD markers. Vegetos. 32(4): 508-520. https://doi.org/10.1007/s42535-019-00069-6

PEREZ-ARBEALAEZ E. 1975. Plants Medicinales y Venenosas de Colombia, Hernando Salazar (Ed.), Colombia: Medellin, 192.

PRAKASH E., SHA VALLI KHAN P. S., SREENIVASA RAO T. J. V. \& MERU E. S. 2006. Micropropagation of red sanders (Pterocarpus santalinus L.) using maturenodal explants. Journal of Forest Research. 11(5): 329-335. https://doi.org/10.1007/s10310-006-0230-y

RAMAKRISHNA D., MURALIKRISHNA N., RAGHU E., SRINIVAS K. \& SHASTHREE T. 2012. Efficient in vitro propagation system via multiple shoot induction and assessment of Clonal fidelity of regenerants in Citrullus colocynthis (L.) Schard. Plant Cell Biotechnology and Molecular Biology. 16(3\&4): 108118.

RANI G. \& GROVER I. 1999. In vitro callus induction and regeneration studies in Withania somnifera. Plant Cell, Tissue and Organ Culture. 57: 23-27. https://doi.org/10.1023/A:1006329532561

REDDY Y. M. \& SARITHA K. V. 2013. In vitro clonal propagation of Gardenia latifolia Ait.: a toy making woody tree. Agroforestry Systems. 87: 591-598. https://doi.org/10.1007/s10457-012-9579-4

ROHELA G. K., JOGAM P., BYLLA P. \& REUBEN C. 2019. Indirect regeneration and assessment of genetic fidelity of acclimated plantlets by SCoT, ISSR, and RAPD markers in Rauwolfia tetraphylla L.: an endangered medicinal plant. BioMedResearch International. Volume 2019, Article ID 3698742, 1-14 pp. https://doi.org/10.1155/2019/3698742

ROMANO A., BARROS S. \& MARTINS-LOUÇÃO M. 2002. Micropropagation of the Mediterranean tree Ceratonia siliqua. Plant Cell, Tissue and Organ Culture. 68: 35-41. https://doi.org/10.1023/A:1012912504288

ROUT G. R. \& SENAPATI K., APARAJETA S. 2008. Micropropagation of Acacia chundra (Roxb.) DC. HortSci (Prague). 35: 22-26.

ROY S., ISLAM M. \& HADIUZZAMAN S. 1998. Micropropagation of Elaeocarpus robustus Roxb. Plant Cell Reports. 17: 810-813.

SAKLANI K., SINGH S., PUROHIT V. K., PRASAD P. \& NAUTIYAL A. R. 2015. In vitro propagation of Rudraksha (Elaeocarpus sphaericus (Gaertn.) K. Schum): a biotechnological approach for conservation. Physiology and Molecular Biology of Plants: an international journal of functional plant biology. 21(4): 611-615. https://doi.org/10.1007/s12298-015-0316-0

SHASTHREE T., CHANDRASHEKAR C. H., SAVITHA R. \& IMRAN M. A. 2012. Effect of various plant growth regulators on callus induction from different explants of Citrullus colocynthis (L.) Schrad. International Journal of Universal Pharmacy and Life Sciences. 2(3): 33-39.

SHA VALLI KHAN P. S., PRAKASH E. \& MERU E. S. 1999. Effect of thiadiazuron and ascorbic acid on recurrent production of plantlets from seeds of Syzygium alternifolium (Wight.). Indian Journal of Plant Physiology. 15(1): 73-76.

SHIH C. D., CHEN J. J. \& LEE H. H. 2006. Activation of nitric oxide signaling pathway mediates hypotensive effect of Muntingia calabura L. (Tiliaceae) leaf extract. The American Journal of Chinese Medicine. 34: 857-872. https://doi.org/10.1142/S0192415X0600434X

SHINDE S., SEBASTIAN J. K., JAIN J. R., HANAMANTHAGOUDA M. S. \& MURTHY H. N. 2016. Efficient in vitro propagation of Artemisia nilagirica var. nilagirica (Indian wormwood) and assessment of genetic fidelity of micropropagated plants. Physiol Mol Biol Plants. 22(4): 595-603. https://doi.org/10.1007/s12298-016-0379-6

SINGH A. K., CHAND S., PATTNAIK S. \& CHAND P. K. 2002. Adventitious shoot organogenesis and plant regeneration from cotyledons of Dalbergia sissoo Roxb., a timber yielding tree legume. Plant Cell, Tissue and Organ Culture. 68: 203-209.

SIRIKONDA A., JOGAM P., ELLENDULA R., KUDIKALA H., MOOD K. \& ALLINI V. R. 2020. In vitro micropropagation and genetic fidelity assesment in Flemingia macrophylla (Willd.) Merr: an ethnomedicinal plant. Vegetos. 1-10. https://doi.org/10.1007/s42535-020-00106-9

SRIDHAR M., THIRUPATHI K., CHAITANYA G., KUMAR B. R. \& MOHAN G. K. 2011. Antidiabetic effect of leaves of Muntingia calabura L., in normal and alloxan-induced diabetic rats. Journal of Pharmacology. 2: 626-632.

YADAV R., ARORA P., KUMAR D., KATYAL D., DILBAGHI N. \& CHAUDHURY A. 2009. High frequency direct plant regeneration from leaf, internode, and root segments of Eastern Cottonwood (Populus deltoides). Plant Biotechnology Reports. 3: 175-182. https://doi.org/10.1007/s11816-009-0088-5 
Suvarchala VANKUDOTH \& al.

YADAV R., YADAV N. \& KUMAR S. 2016. An improved micropropagation and assessment of genetic fidelity in multipurpose medicinal tree, Acacia auriculiformis. Proceedings of the National Academy of Sciences, India - Section B: Biological Sciences. 86: 921-929. https://doi.org/10.1007/s40011-015-0550-9

YASUNAKA K., ABE F., NAGAYAMA A., OKABE H., LOZADA-PÉREZ L., LÓPEZ-VILLAFRANCO E., MUNIZ E. E., AGUILAR A. \& REYES-CHILPA R. 2005. Antibacterial activity of crude extracts from Mexican medicinal plants and purified coumarins and xanthones. Journal of Ethnopharmacology. 97: 293-299. https://doi.org/10.1016/j.jep.2004.11.014

YUSOF M. M., TEH L. K., ZAKARIA Z. A. \& AHMAT N. 2011. Antinociceptive activity of the fractionated extracts of Muntingia calabura. Planta Medica. 77: PF21. https://doi.org/10.1055/s 0031-1282409.

ZAKARIA Z. A., SULAIMAN M. R., JAIS A. M. M., SOMCHIT M. N., JAYARAMAN K. V., BALAKHRISNAN G. \& ABDULLAH F. C. 2006a. The antinociceptive activity of Muntingia calabura aqueous extract and the involvement of L-arginine/nitric oxide/cyclic guanosine monophosphate pathway in its observed activity in mice. Fundamental \& Clinical Pharmacology. 20:365-372. https://doi.org/10.1111/j.1472-8206.2006.00412.x

ZAKARIA Z. A., FATIMAH C. A., JAIS A. M. M., ZAITON H., HENIE E. F. P., SULAIMAN M. R., SOMCHIT M. N., THENAMUTHA M., KASTHURI D. 2006b. The in vitro antibacterial activity of Muntingia calabura extract. International Journal of Pharmacology. 2(4): 439-442. https://doi.org/10.3923/ijp2006.439.442

ZAKARIA Z. A., KUMAR G. H, MOHD ZAID S. N. H., ABDUL GHANI M., HASSAN M. H., MOHD NOR HAZALIN N. A., KHAMIS M. M. \& DEVIR. G. 2007a. Analgesic and antipyretic actions of Muntingia calabura leaves chloroform extract in animal models. Oriental Pharmacy and Experimental Medicine. 7: 34-40.

ZAKARIA Z. A. 2007b. Free radical scavenging activity of some plants available in Malaysia. Journal of Pharmacology \& Therapeutics. 6: 87-91.

ZAKARIA Z. A., JAIS A. M. M., MASTURA M., MAT JUSOH S. H., MOHAMED A. M., MOHD JAMIL N. S., ROFIEE M. S. \& SULAIMAN M. R. 2007c. In vitro anti staphylococcal activity of the extracts of several neglected plants in Malaysia. International Journal of Pharmacology. 3: 428-431. https://doi.org/10.3923/ijp.2007.428.431

ZAKARIA Z. A., HASSAN M. H., NURUL AQMAR M. N., ABD GHANI M., MOHD ZAID S. N., SULAIMAN M. R., HANAN KUMAR G. \& FATIMAH C. A. 2007d. Effects of various nonopioid receptor antagonist on the antinociceptive activity of Muntingia calabura extracts in mice. Methods Findings in Experimental and Clinical Pharmacology. 29: 515-520.

ZAKARIA Z. A., MUSTAPHA S., SULAIMAN M. R., ABDUL MANAN MAT JAIS A. M. M., SOMCHIT M. N. \& ABDULLAH F. C. 2007e. The antinociceptive action of aqueous extract from Muntingia calabura leaves: The role of opioid receptors. Medicinals Principles Practice. 16: 130-136.

ZAKARIA Z. A., HAZALIN N. A. M. N. \& ZAID S. N. H. M. 2007f. Antinociceptive, anti-inflammatory and antipyretic effects of Muntingia calabura aqueous extract in animal models. Journal of Natural Medicines. 61: 443-448.

ZAKARIA Z. A., SOMCHIT M. N., SULAIMAN M. R., MAT JAIS A. M. \& FATIMAH C. A. 2008. Effects of various receptor antagonists, $\mathrm{pH}$ and enzymes on Muntingia calabura antinociception in mice. Research Journal of Pharmacology. 2: 31-37. https://medwelljournals.com/abstract/?doi=rjpharm.2008.31.37

ZAKARIA Z. A., SUFIAN A. S., RAMASAMY K., AHMAT N., SULAIMAN M. R., ARIFAH A. K., ZURAINI A. \& SOMCHIT M. N. 2010. In vitro antimicrobial activity of Muntigia calabura extracts and fractions. African Journal of Microbiology Research. 4: 304-308.

ZAKARIA Z. A., MOHAMED A. M., JAMIL N. S. M., ROFIEE M. S., HUSSAIN M. K., SULAIMAN M. R., TEH L. K. \& SALLEH M. Z. 2011. In vitro antiproliferative and antioxidant activities of the extracts of Muntingia calabura leaves. American Journal of Chinese Medicine. 39: 1-18.

How to cite this article:

VANKUDOTH S., DASARI R., CHIRUMAMILLA R., GOPU C., JOGAM P., KOTA S. \& TADURI S. 2020. Micropropagation of Muntingia calabura L. and assessment of genetic fidelity of in vitro raised plants using ISSR and RAPD analysis. J. Plant Develop. 27: 33-45. https://doi.org/10.33628/jpd.2020.27.1.33 